Making 'what works' work

enacting evidence-based pedagogies in early childhood education and care

Plum, Maja

Published in:

Pedagogy, Culture and Society

DOI:

10.1080/14681366.2016.1270349

Publication date:

2017

Document version

Early version, also known as pre-print

Citation for published version (APA):

Plum, M. (2017). Making 'what works' work: enacting evidence-based pedagogies in early childhood education and care. Pedagogy, Culture and Society, 25(3), 375-388. https://doi.org/10.1080/14681366.2016.1270349 


\title{
Making 'what works' work: enacting evidence-based pedagogies in early childhood education and care
}

\begin{abstract}
Inspired by perspectives from Actor-Network Theory, this paper challenges key assumptions in evidence-based pedagogies. Through a multi-sited analysis of the evidence-based pedagogy 'Dialogic Reading' (DR) in the area of Early Childhood Education and Care in Denmark, the paper explores how DR is enacted as part of an assemblage of tests, research in the field of audiologopedics, classifications of reading disabilities, day care centres and the book as a 'nice experience'. It also explores how DR is organised in a local day care centre, hereby organising objects such as dolls, books, children and a mattress. As such, the paper shows how DR, as an evidence-based method, is established through concrete relations, rather than abstracted and universal principals. It argues that these relations stabilising DR are never enacted once and for all, but require continual work to be held together as a method that 'works'.
\end{abstract}

\section{Keywords}

Evidence, evidence-based methods, scripted pedagogies, politics, Early Childhood Education, day care, Actor-Network Theory, Dialogic Reading.

\section{Introduction}

Reforms aiming to optimise the outcome of public education have swept across most Western countries, which has placed emphasis on developing standardised curriculums and evidence-based methods, allegedly ensuring a predictable outcome in relation to the efforts (and resources) being invested. As such, the idea of 'what works' becomes a mantra in educational policy (Ball 2007, Biesta 2010, Vandenbroeck, Roets, and Roose 2012). Within the field of Early Childhood Education and Care (ECEC) these global trends have been prominent, not only in the sense of reforming what is already there, but as an increased administrative and political interest in 'the early years' (Dahlberg and Moss 2005). Thus, the first national curriculum for day care (crèches and kindergartens) was developed in several countries during the first decade of the new millennium (Cheeseman, Sumsion, and Press 2014, Pettersvold and Østrem 2012, Plum 2012a). Often these kinds of governmental initiatives are supported by strategies typically referred to as the 
'professionalisation' of teaching and non-teaching staff in the field of ECEC (Urban 2008, Osgood 2009, Plum 2012b). As Urban (2008, 142) notes, this conceptualisation of professionalisation often entails an idea of evidence-based practice, in which the nursery teacher becomes a professional by applying scientific knowledge through a particular method that promises to deliver a predetermined outcome. Professionalism in this way comes to refer to the importation of knowledge into practice through the mean of a specified method ${ }^{\mathrm{i}}$. This also implies that scripted pedagogies are in high demand, as through meticulous step-by-step descriptions they guide the teacher in how to act, the questions they should pose, etc. (Wyatt 2014).

Evidence-based practices and scripted pedagogies (often referred to as either evidence-based or scientifically-based) have been discussed and criticised from different perspectives in the field of ECEC. It has been argued that nursery teachers cannot base their practice directly on research evidence because education is an open-ended endeavour and because evidence needs to be integrated as part of teachers' funds of knowledge (Hedges 2012). Likewise, the idea of a universal child embedded in the one-size-fits-all approach has been critiqued in terms of its inability to adjust to the reality of children being from different cultural backgrounds and settings (Ede 2006, Wyatt 2014). From another angle, it has been analysed how scripted pedagogies form the nursery teacher's instruction and perception of children's activities in ways in which what is not planned, tested or in the script become marginalised; and where the development of children potentially becomes a question of fostering narrow and predefined skills (Schmidt 2013a, Parks and Bridges-Rhoads 2012).

Inspired by perspectives from Actor-Network Theory (ANT), this paper takes another approach, exploring how a particular evidence-based pedagogy called 'Dialogic Reading' (DR) is made to work in Danish ECEC. Thus, the purpose here is not to perform a general debate about how the relationship between research and practice in education is or should be (Hammersley 2007, Biesta 2007, Vandenbroeck, Roets, and Roose 2012). Rather, the paper challenges the idea of 'what works', not by questioning whether it (really) works, but by asking how a concrete method, namely DR, is made to work. This refers to all of the work put into making DR an evident - stabilised, legitimate and 'professional' - method in Danish day care. The paper poses questions such as: What kinds of assemblages does DR become part of as this method travels from the US (where it originates) to Denmark? And how is it stabilised and blackboxed as an evidence-based method through being linked to researchers, test-developers, the Crown Princess Mary, etc.? Furthermore, 
the paper asks how DR is enacted in a Danish day care. What kind of effort do nursery teachers put into the organisation of their everyday practice in order to perform DR, and how are elements such as books, mattresses, dolls, children and indeed nursery teachers themselves translated in that process?

\section{The Danish case}

In Denmark almost 97\% of children from 1 to 6 years of age attend day care (kindergarten and crèche). The centres are staffed by nursery teachers, who have a bachelor degree from a university college, and assistants, who are typically not formally educated within the field. During the first decade of the new millennium, the area of ECEC underwent profound changes in Denmark. In 2004, the first national curriculum was implemented and although it is still not standardised in terms of a scripted curriculum at the national level, the emphasis on scripted pedagogies and evidence-based methods that can be imported to meet specified aims have gained increasing influence (Ahrenkiel et al. 2012, Krejsler 2013). A study from 2012 (Buus et al.) conducted in three different municipalities shows that $80 \%$ of the day care institutions work with - or are preparing to work with - evidence-based programs, often following a meticulously described scripts for carrying out the method in question. In the area of language development - an area that has gained attention, research funding, especially designed programs, national testing, etc., since the first national curriculum was introduced (Schmidt 2013c) - DR is presented as the most effective evidence-based method to develop and support children's language acquisition (Bleses 2011, 5). DR is presented not only as a model of how to read picture books for children aloud, but of how to read them whilst engaging in a dialogue about the theme of the book, the words, the author, and so on. The method entails three steps: 1. 'Before reading': talking about the cover page, the title and the author, posing questions that anticipate what is to come, and creating a safe environment and mutual joy about the book. 2. 'During reading': talking about the pictures and the different words, listening, elaborating and posing open-ended questions that will support the child's narrative skills and vocabulary. 3 . 'After reading': playing games or activities introduced in the book to repeat the words and phrases being used. These three steps are described in detail in relation to different children's books, suggesting questions to pose, words to practice, games to play, and other learning techniques. ${ }^{\text {ii }}$

In the following sections, I will present my analytical approach using Actor-Network Theory and the materials on which I base my analysis. Within this framework, I will show how DR in 2005 makes its entry in to the area of ECEC in Denmark through worries related to the Danish reading 
standards as described in the PISA (Programme for International Student Assessment) reports; in this process enrolling researchers in the field of audiologopedics, day care, the book as a "nice experience', tests and a test-developer, categories of phonological awareness and vocabulary. A potential lack of reading disability is hereby generalised to the entire population of children and thus made into a risk in need of action. Furthermore, I will argue that DR becomes blackboxed through links forged between researchers, administrative concerns and the Crown Princess Mary foundation, stabilising it as an objective, effective and 'good' method. I will then turn to a case study of a Danish day care centre to analyse how the book - and other objects used in the day care centres - become mobilised and stabilised in particular ways as they are enacted as part of carrying out DR. I will point to the way in which the connections embedded in DR are translated and become part of the action; not a transmission of pure scientific knowledge through the method, but a process of continually juggling the complexity of everyday life in day care, so that it becomes possible to carry out as DR. I will conclude by pointing to the paradox that the performance of evidence-based pedagogy is seen as a way of professionalising the field of ECEC; however, the extensive work needed to enact DR as an evident method is not recognised as part of this professionalism.

\section{Actor-Network-Theory and Dialogic Reading as a multiple assemblage}

In education research, inspiration from Actor-Network Theory (ANT) has become more prominent, with authors analysing and discussing the distributed character of knowledge and the socio-material processes of learning (Fenwick and Edwards 2010, Sørensen 2009, Mulchany 2006, Nespor 2004). Stemming from the field of Science and Technology studies, ANT studies share an interest in the ways in which knowledge or scientific facts are produced - and as such stabilised and blackboxed as 'facts' or 'objects' - in a web of connections between different elements. Elements are to be understood in a broad sense as human and non-human entities; and is as such a way to avoid a traditional ontological divide between humans as agents and things as passive objects (Latour and Woolgar 1979, Callon 1986, Latour 1999). Things we perceive as things or actors (political reforms, airplanes, asthma-inhalers) are instead analysed as networks - or assemblages performing their agency not by inner properties, but through the connections that make up the force or power to act as a unified entity (Law 2003, Callon and Law 1997, Prout 2005, Hamilton 2011). Central to ANT approaches are, thus, to explore the phenomenon of interest, not by tracking it down to an origin, or explaining it by pointing to a cause, but by analysing it as an enactment. The 
term enactment is suggested by Annemarie Mol (2003, p. 33,40f) as a way of emphasising that things are not things 'out there' as if isolated entities we can strive to come to know. Things - or objects - take on their particular shape in and through activities forming an assemblage that stabilises reality in particular ways. As she argues, atherosclerosis (as a clinical disease) is not a stable object, but enacted (emerges as a disease) through rooms, doctors, patients, questions posed and schemes filled out. Thus, the object is not out there to be known if you cut through the complexity. Rather the act of cutting complexity into a stable form - stabilising it so that we can talk and act upon it as a natural and neutral arrangement - is a way that objects are done or enacted. This enactment involves links forged to different elements, enrolling them as part of the action, and as such making up the assemblage or the acting network. For instance, as I will show, DR is not just a pure representation of children's language development put into an effective method. To make DR emerge as an evidence-based pedagogy in the field of ECEC in Denmark requires connections made between a ministry, researchers, tests, day care centres, books, categories of reading disabilities and worries related to reports from PISA. In this way, DR is act of doing - it is an enactment. Another kind of enactment then the one carried out as DR is performed in a local day care centre. Because DR is not just there as a stable thing; it comes into being through its concrete relations. Its ontology is multiple (Mol 2003) .

Thus, an ANT approach is chosen because it reverses the question of knowledge: Instead of asking how evidence-based methods are biased through different kinds of implementation or interpretation, the approach makes it possible to ask how knowledge became and becomes knowledge in the first place. That is, it places knowledge as a matter of ontological engagement rather than epistemological distance. As such, the approach makes it possible to challenge the evident nature of DR by asking how this universal, well controlled and neatly ordered method is a result of multiple connections and ongoing work to cut complexity into a stabilised form. Emphasising this ongoing work, I analyse DR as an enactment, stabilised in different ways across the reports and web platforms, introducing it as a method suitable for Danish day care and the group room in a local day care centres. I perform this multi-sited analysis as a way of exploring the multiple ontology of DR. Thus, my point is not to use the ethnographical work in a day care institution as an example of how the macro is transferred to the micro, or how centrally formulated intentions are implemented in everyday life. The point is to challenge such ideas of knowledge (and knowledge transfer) by analysing how a method 'that works' is made to work in different forms of assemblages. That is how DR is enacted and as such becomes connected to different socio-material entities, such as 
books, scripts, categories, boxes, dolls, children, researchers and nursery teachers, not only translating DR, but also translating for instance what a book is. Translation, here, does not mean putting one predetermined entity into another language without losing its identity. Translation (Latour 1999, 58, Law 2003) points to the social-material organisation in which complexity is organised into a form making it stable and as such recognisable as, for example, DR. Making 'what works' work embeds a reference into this analytical notion of translation, in the sense that I am interested in how a particular method is organised and as such becomes a naturalised - and powerful - part of Danish day care through links forged and efforts made. That is, through work being done.

The inspiration from ANT perspectives becomes a way for me to relate to DR as an evidence-based pedagogy. This connection is very much made in the style of writing. To relate to the world as a matter, not of subjects who know or act upon objects, but as assemblages enrolling different elements in an enactment stabilising something as an object, undermines the subject/object divide. Thus, in my analysis I write about actions taking place as things come together in a web of connections: I write about connections made between researchers, day care centres, tests and books; as opposed to writing about researchers who use tests on children who read books. Writing about the world in this manner is as such an attempt to analyse it in a particular way.

\section{Documents and fieldwork}

My analysis is based on documents as well as ethnographical fieldwork. As part of a larger project exploring how nursery teachers create and use knowledge as part of their everyday practice, I did fieldwork in two Danish day care centres for three months in the spring of 2014. Both day care centres worked with DR as a method and introduced it to me very early on as part of their practice informed by knowledge and, as such, something that was central to their professionalism. Following the everyday operation of these day care centres, I became interested in the forms of organisation taking place as DR was performed. Law (1994) points to the ways in which elements can be translated differently, yet exist side-by-side in an organisation. For instance, in my case, the book caught my attention because it was part of the everyday interior, yet once it was related to DR it was put in a box with other items and stored away in a closet-like room only to be taken out at particular hours. Thus, the book as a socio-material element was enacted quite differently in DR as opposed to the way it was mobilised - organised and organising - at 'rest-time' at midday. Therefore, I became intrigued by the different kinds of efforts and elements that were put into the 
performance of DR, constituting what was referred to as 'knowledge' or 'professionalism' by the pedagogues. Against this background, I started researching when this method was first mentioned and described in Denmark, how it was described and in relation to what. This led me to different reports and two web-based platforms that currently sell or offer this method to Danish day care practitioners. In this paper, I base my analysis on these documents, but relate them to changes within the field of ECEC in Demark during the last decade. The fact that I have not followed the method of DR beyond what I can tell from reports, webpages and books, of course limits my view. Despite the limited space of this paper, this approach has served the purpose of exploring important moves through which DR has become a stabilised assemblage in Denmark.

In the paper, I also use examples from my observation of one of the two day care centres, called the Spindle ${ }^{\mathrm{iii}}$, located in a provincial town of Denmark. In the Spindle, I primarily followed two different nursery teachers, who both worked with a group of 20 children aged between 9 months and 4 years. Drawing on an ethnographical tradition (Gordon, Holland, and Lahelma 2001, Pole and Morrison 2003) translated through ANT inspirations ${ }^{\text {iv }}$, my focus was directed towards the meaning making embedded in the day-to-day practices. In other words, I examined how elements such as dolls, boxes, books, time, children and categories (of e.g. age) were handled and connected in ways that made sense or were seen as relevant or meaningful to the nursery teachers.

\section{PISA problematisations and the enrolment of day care, audiologopedics and G.J. Whitehurst}

At the beginning of 2005, a report called 'Dialogic Reading in Day Care' was published (Jensen 2005). The report was part of a larger project financed by the Ministry of Family and Consumer Affairs (which at this point in time was in charge of the area of day care) aiming to introduce the notion of learning in Danish day care. Thus, parallel to this project the Danish government had worked to pass the first national curriculum for ECEC; a law which was put into action in August 2004. The curriculum was formulated in categories of so-called 'learning themes' that the children needed to develop through their time spent in day care. One of these themes was language (Socialministeren 2003). As opposed to the other themes, namely personal competence, social competence, body and movement, nature and science, and cultural expression and cultural values, language and language development was seen by the Ministry as an area in need of particular research interest. That is why the project on DR was formulated. The project aimed to both develop methods and ideas of how nursery teachers could work with read-aloud books, and to test the effect 
of such methods and ideas in terms of children's vocabulary and phonological awareness (Jensen 2005, 3).

Based on a study by Callon (1986), Hamilton (2011) suggests that the moments identified by Callon as central to the stabilisation and blackboxing of a network can be used as an inspiration to analyse educational reform. As such, Hamilton moves the perspective into educational reform and in this way helps me to grasp the moves made to stabilise DR as an evidence-based method suitable for Danish day care. Thus, Hamilton talks about problematisation as a way in which problems are framed, prompting actions and defining elements into a network, making them indispensable to the action. This might involve persons, organisations, objects, but also metaphors and classifications (ibid, 60). In this process links between other allies are weakened, channelling action and resources into new alliances and, as such, not only enrolling new actors, but also redefining the identities needed to be performed. In this way a network is mobilised as a united voice that is no longer questioned, but blackboxed as a natural and unified entity (ibid, 61).

Following this approach, it is interesting how DR makes its entry into the Danish field of ECEC as part of a broader political problematisation of the Danish school system spurred by the PISA ${ }^{\mathrm{v}}$ assessments. As in many countries, the graphical listings of PISA and the media upheaval that follows have produced a diagnosis - often referred to as a shock (Grek 2009) - which in the Danish case comes to define the Danish school system as a failure. In the assessments Danish pupils are listed among average in terms of reading abilities which in Denmark is portrayed as 'lagging behind' in the global knowledge competition (Plum 2014). Across the Ministry, the municipal level and the union for nursery teachers, the reference to 'the Finnish child' (Finland getting high scores in the assesments) is a metaphor for being ahead in the global knowledge competition. This metaphor is central to the rationale behind the increased governmental interest in the area of ECEC and the DR project (Hansen, Bech, and Plum 2004). In the report 'Dialogic Reading in Day Care', the links made to the ranking of nations in the PISA reports, and the 'problem' it comes to define in terms of Danish pupils' reading abilities, is not explicitly stated, but implied in terms of 'poor reading skills' and a 'preventive effort in relation to future reading abilities'. It states:

Children need a good foundation in terms of language, and an early preventive effort in relation to future reading abilities is better than later efforts to repair poor reading skills [...] Children's vocabulary as they begin school is an indicator of their later abilities to read. (Jensen 2005, 3). ${ }^{\mathrm{vi}}$ 
Thus, the classification of reading abilities and disabilities, metaphors of prevention and reparation, the school as an objective for the activities in day care are all connected. Likewise, a test developer, two research assistants and a professor from the research field of reading disabilities are enrolled together with five different day care centres to carry out the project (Jensen 2005, 1). As part of the problematisation, a new alliance is established in this way between the Ministry in charge and researchers in the fields of audiologopedics ${ }^{\mathrm{vii}}$ and Early Childhood Education and Care. They channel resources into the project and appoint the researchers, tests and ECEC at the centre of the action. In this process the potential shortcoming (reading disability) and the categories it embeds becomes part of the problematisation, which generalises that all Danish children are at risk of experiencing the same difficulties, hereby making DR a relevant answer to all Danish day care.

One of the ways in which day care is enrolled as part of DR is through the book as an already well established object of Early Childhood Education and Care. As stated in the report: 'reading aloud is a normal activity in day care, and something that most people relate to as being cosy and nice.'

(Jensen 2005, 3). As the report has been made into a handbook for the education of nursery teachers at university colleges, it is emphasised that the purpose of conducting DR is primarily having ' $a$ good experience about a book,.... The fact that Dialogic Reading also stimulates language development is a trade off that it can only be recommended that nursery teachers make use of.' (2007:24). In this way, DR is dismantled as a potential threat to what is typically described as the Nordic tradition of day care. Here, day care is not seen as a mere preparation for school with school-oriented activities. Rather, emphasis is placed on play and the child taking their own initiative. Efforts to turn the day care centre into a home-like environment, as opposed to a school setting, are reflected, for example, in the term 'living room' (meaning classroom or group room) (Jensen 2014, Kristensen 2015). As such, the 'niceness', 'cosiness' and 'good experience' associated with the book can be seen as connections made to traditions that are valued and already there, making DR a part of this tradition rather than an intruder. In this process the book is reinvested, hinging on the values it already holds; however, adding a strict methodological approach for the realisation of language development, thereby reshaping what a book is in ECEC.

\section{Head Start and the embedded 'truth' of a universal child}

Central to the connection between reading disabilities, the book, day care centres, the Ministry, the researchers, and the test developer is the figure of G.J. Whitehurst. I am calling him a figure, as the reference to this name not only appears several times in the report from 2005, but stabilises itself as 
a synonym for DR in the later popular descriptions of DR. Whitehurst in this way becomes a reference in its own right - the inventor of DR as a method and the guarantor for its success. DR emerged as part of the American Head Start Program, in which it was initially developed as a strategy for parents to read to their children. It was later developed and tested in preschool with other researchers and families being involved in this process (Whitehurst et al. 1988, Zevenbergen, Whitehurst, and Zevenbergen 2003). However, this involvement of parents, children, American preschools and the Head Start Program disappear as DR is translated into a Danish assemblage. In Denmark Whitehurst invented DR; and DR is considered a unified thing that can be transported from one site to another. That is, the connections that made up DR disappear from sight.

The Head Start Program was established in the US in 1964 as part of its War on Poverty programs. Its aim was to prepare pre-schoolers from low-income families to successfully complete elementary school. A prominent concept within developmental psychology at that time, the idea of a universal child was inherent in the Head Start Program. The poor (and often immigrant children) were seen as children who were not different from others by nature, meaning that with the right amount of educational effort they could be liberated from their deprived situations through cognitive growth and development (Fass and Grossberg 2012, 101, Morrow 2006, 36-37). In this way, Head Start not only embeds 'truths' (Foucault and Lotringer 2007) about a universal child, which have later been heavily contested and discussed internationally, including in the field of ECEC in Denmark (Kampmann 2003, Prout 2005), it also emphasises skills for school readiness. This is something the progressive movement in Danish ECEC has argued against, instead stressing that kindergartens and crèches should be places in their own right - where the child is seen as being rather than as becoming (Brembeck, Johansson, and Kampmann 2004). However, as DR is translated into a Danish assemblage these truths, become central to the idea of language as a universal system that all children can develop with the right kind of training, and that day care centres have a central role to play in this kind of training, making children ready for school. In this way links are weakened between former allies of the progressive movement and Kindergartens, subtly introducing not only categories (e.g. phonological awareness, reading disabilities) and fields of research (e.g. audiologopedics) that have not been prominent in ECEC, but also reshaping the purposes and truths of ECEC.

\section{Blackboxing DR as a scientific, technical and 'good' method}


In the report from 2005, as well as the handbook from 2007, DR is presented as a 'method' (word emphasised (Jensen 2007:23)) with a model of three phases (as described in the introduction). This handbook also presents scripts in terms of suggestions for questions to pose, things to play etc. for five different children's books. This emphasis on method is repeated in the description of DR on two different web platforms that were launched in the years from 2010 to $2012^{\text {viii }}$. In 2010 the Mary Foundation (a private foundation established by the Danish Crown Princess Mary) takes up DR as part of a strategy to make a difference to children's lives, by providing day care centres with a method that will help children in general and children with 'limited language skills' in particular ${ }^{\mathrm{ix}}$. Toolkits for delivering DR can be bought from their homepage and contain an overall introduction to the method, several children's books and instructions on questions to pose and games to play in relation to the books. Thus, DR has been turned into a commodity: a packaged method that can be bought, delivered and used as a tool to solve problems. Another web platform offers 'sprogpakken'/ The Language Package. This package was developed through a government grant of 34 million Danish Kroner (about 4.5 million Euros) in 2010. The grant was used to develop the online platform and conduct in-service training for nursery teachers based on a research review determining which methods are the most appropriate and effective. The purpose was to bring the latest knowledge and evidence-based research to nursery teachers in the form of methods and concrete tools they could use to carry out evidence-based activities that could accelerate a child's language acquisition (Jensen 2014) $)^{\mathrm{x}}$. The grant was received by three parties, namely the research centre 'Centre for Children's Language', three University Colleges and the 'Centre for Competence Development in the Public Sector', a centre funded by all municipalities for the education and development of their staff. This emphasis on DR as a method (that is, a systematic approach with well-defined steps that can be abstracted from one context and implemented in another) can be seen as an attempt to forge a link to concerns embedded in current administrative practices - a link that places the Centre for Competence Development in the Public Sector as being central to the action needed. Thus, concerns with the most effective solutions (cost-benefit wise) to 'problems' within the welfare state have increasingly been articulated as a matter of finding the right 'cure' or the right method, and in this way enhance the quality and professionalism of the public sector through 'evidence' and 'evidencebased practice' (Krogstrup 2011). In this strategy of delivering professional development a web platform and in-service training are enrolled as effective means to transmit a standardised, universal method. 
Central to DR - and the resources being channelled into the initiative - both as part of the Language Package, the Mary foundation and the report 'Dialogic Reading in Day Care' is that tests, reviews and researchers are enrolled in the enactment of the method stabilising it as an objective and effective intervention. The link to scientific research is not only reinforced through the figure of Whitehurst, but also through links made to Danish researchers - primarily within the field of audiologopedics. In Denmark, they are the ones conducting the tests and reviews or, in the case of the Mary Foundation, serving as an expert panel in the development of the method ${ }^{\mathrm{xi}}$. In this way, DR can be said to be blackboxed. That is DR gains a stability in which all the work put into making it an evidence-based pedagogy is dissolved, just as the multiple connections enacting it as an objective and effective method disappear as connections. It becomes an evident method based on facts. The way in which the Mary Foundation has adopted DR is interesting in this respect because, as a foundation funded by a royal figure, its strategies and the tools it offers for educational purposes cannot be seen as political. A royal figure cannot act in political way, but they can in a philanthropic way. Through the Mary Foundation, DR is mobilised not only as an objective (scientifically grounded) and technical (targeting a precise problem) method, but also as a good (in the sense of doing a good deed) method.

Having shown how DR is translated into a Danish assemblage of tests, audiologopedics, the Ministry in charge of ECEC, day care centres, the Crown Princess Mary's foundation, web-based platforms and the book as a 'cosy' and 'nice experience', I will now turn to another setting in which DR is enacted. Instead of focusing on how DR, through PISA problematisations and categories of reading disabilities, is made to work through the assemblage analysed above, I will pay attention to the way DR is translated - but also translating elements - in a local day care called the Spindle.

\section{The book and the blue mattress}

At my first visit to the Spindle, I was shown around by the two nursery teachers whom I was to follow in the coming months. One of the first places they took me to was a small room, much like a closet, in which crayons, paper, scissors and other kinds of material were placed. Several big plastic boxes were placed on one of the shelves. Rikke, one of the nursery teachers, took out a box and opened it for me to see. It contained a book, different kinds of dolls and other items, such as a tiger mask and a dresser from a dolls house. She told me that these were the boxes they often used to perform Dialogic Reading; and explained how they have found what she calls 'concretes' (part of DR in one of its versions) - that is, dolls and figures symbolising what happens in the book and thus 
making it concrete. She told me that DR is a method that 'really works' and gave an example of Adam, who sits with his lunchbox, turning it upside down and saying 'it is empty', just as they had talked about the dresser being empty in the book 'Kaj is dangerous'. So, as she expressed, it 'you can really tell that he has learned something' (observation book 1, 2014). During my stay in the Spindle, the nursery teachers several times referred to DR as part of their professionalism; or as one of them said 'I do not feel I have done any professional work today - I miss my boxes' (observation book 2, 2014). As such, DR is established in this particular day care centre as something that works and that produces significant results in terms of learning. As DR is translated into the Spindle the connections to poor learning results (PISA), administrative concerns about finding the right cure and audiologopedic awareness, in terms of children's vocabulary, are as such present, though never directly articulated. In this process of translation DR enrols elements, such as particular places (the closet), plastic boxes, dolls and books. It also enrols the nursery teachers, who present DR as important to their work and as a central part of their professionalism.

What is interesting here is that DR in the report 'Dialogic Reading in Day Care' enrolled Danish day cares through a connection to the book as something which was already part of the everyday life of day care, and part of a cosy and nice experience. Thus, DR hinged on elements of the socalled Nordic tradition emphasising the homelike environment. However, as DR comes into the Spindle, multiple ways of enacting the book becomes present. As such, the book takes on multiple ontologies during the day. Once enrolled as part of DR, the book is physically removed from the shelves in the group room, put into boxes, and placed in the closet until it is time to read them. That is, as the book is taken in as part of DR, it is taken out of its regular setting in the group room.

Following the book as part of everyday life at the Spindle, books are placed on the shelves in the group room where Rikke is a nursery teacher. Some books are taken down by children during the day; sometimes they are stacked up as towers to be taken down and then put back up again. Sometimes the books are read by the nursery teacher while they, for instance, point to pictures of animals saying 'moo' (if it is a cow). Moreover, the notion of a book reappears every day at around 12 o'clock. However, in this timeslot the book is enacted not through pictures, written words and paper, but through a CD player. As such, the book is not just there as a stable element, but is translated in particular ways in DR. To shed light on the enactment of the book as part of DR, the following example will serve as a contrast, showing a quite different enactment of the book.. 
It is midday; most children have been tucked into their strollers for their midday nap. Seven children are still in the group room, three of them (the youngest) waiting to be tucked in. One of them is finishing lunch at the table. The nursery teacher, Mona, is in the group room. Four of the oldest children (4 years) are told by Mona to go to the blue mattress placed in the corner of the room. They each get a blanket. Mona approaches one of the girls, Cecilia, with a beanbag, turning Cecilia round on her stomach whilst saying, 'try rolling around on your stomach Cecilia'. She gently strokes her hair, putting the beanbag on her back. She goes towards the CD player, placed on one of the shelves, gazing back at the children and then turning on the story 'Little Frog'. She looks out into the room towards the two younger boys playing in the middle of the room. She walks to the blue mattress and lies down next to Cecilia fronting her front. She puts her arm around Cecilia's back as Cecilia raises her head and looks at herself in the mirror on the wall behind the mattress. Mona strokes her hair and gently pushes her head back. She says 'shhh' if anybody speaks. During the time the book is read aloud on the CD player, Mona continuously directs her body towards different children: Sebastian passes her and she lifts her arm towards him, pulling him down beside her. He walks away again. Lotte, another child who lies on the mattress, gets up and moves towards Mona. Mona's arms reach towards her as she lies down next to her, then again placing a hand on Cecilia's back. Sebastian walks around with a teddy bear; he passes some shelves and turns on a toy which makes noises. Mona lifts her head, gazes at the source of the sound, gets up, turns off the sound and places the toy on a shelf out of the children's reach. Then she lies down again. (Observation book 1, 2014).

In the episode above, the book is connected to a particular timeslot, the children, the nursery teacher, a blue mattress, blankets, a beanbag and a CD player. This translates the book as an object associated with 'rest', in which the voice is separated from the nursery teacher's. She is not reading aloud. Instead she is connected to the book in an assemblage where she is enforcing silence (by saying 'shh', turning the noisy toy off and gesturing to the eldest children to keep still). Thus, through Mona connections are made between blankets, a beanbag, a mattress and children organising the body of the child to be placed and held in particular (resting) ways. Simultaneously, upcoming connections between for instance the sound of the toy, the voice of children and the CD player, the mattress etc. are dissolved. That is, they are silenced hereby stabilising the book 'Little Frog' as the core voice and the primary activity. As such, the book is here translated as a mean of 
rest, in which children (and the nursery teacher) can swop places, or for the youngest children move around the floor, but where sounds seem to make the assemblage fall apart, thus calling for actions to be removed. The book becomes part of an enactment in which the children, beanbags, blankets, and other items are enrolled and stabilised in silenced ways. As I will show in the following section, this way of enacting the book, places in the room and the body of the child (and the nursery teacher) differs as the book is translated as part of DR.

\section{Enacting Dialogic Reading}

In the Spindle, the boxes - each containing a book, a script and different 'concretes' (tangible symbolic items), kept in the closet-like room - are regularly taken out to carry out DR. In the following episode, the nursery teacher, Rikke, has collected two different boxes (one book in each) and taken them to the group room. Christina, a new assistant who just started her training at the Spindle two days before, is in the group room together with five children aged 2-3 years. Catherine, a 9-month-old girl, has been tucked into her stroller outside for a morning nap.

The children and Christina are sitting on the blue mattress so that 'their back touches the mirror', as Rikke says. That is, the children are sitting in line in physical contact with the wall behind them. Rikke sits with one of the boxes in front of her (the other box is placed in the windowsill, out of reach from the children). She sits at the edge of the mattress so that her front is turned towards the children with the box between her and the children. She slowly opens the box while looking around at the children (as in rousing the excitement). She picks up the book 'Kaj is dangerous', shakes her entire body as if she was afraid, while she reads aloud the title. She repeats the title while pointing to each word 'Kaj' 'is' 'dangerous'. She reaches into the box and pulls out a small doll: 'This is Kaj'. She places the doll on top of the box. Her hand goes down again and up comes a new doll: 'This is mum'. And again: 'This is Lise'. She lifts up the book so that the front faces the children, turns the front page and shows the first pages inside which are red. She says, 'it is red', she opens her mouth and widens her eyes (as in being surprised). She repeats 'red'. She turns to the first page, still with the book facing the children, her gaze shifting between the children and the book. She reads out loud 'here is Kaj'. One of her hands holds the book while the other reaches for Kaj, the doll, lifting him up into the air and placing him back on top of the box. She reads out loud, 'here comes Lise'. She holds the doll, Lise, up into the air [...]. She reads out loud, 'Kaj puts on a tiger mask' 
(emphasis put on the ' $t$ '-sounds). She takes a tiger mask from the box, holding it in front of her face while leaning her head towards a child saying 'wauhhh'. She repeats the movement and the sound with each child. The children are laughing. She reads on, playing with the dolls to illustrate the story. She pulls figures shaped like the tiger and a dresser from the box. She asks the children, 'What comes next?', 'What is in the dresser?', etc. Then all of a sudden she stops reading. She looks up (as if listening for something), looks towards Christina while saying 'I think it is ours'. She looks towards the window. Christina says 'yes, if it is Catherine'. Rikke looks at Christina, but as Christina doesn't move, Rikke gets up, walks towards the door while saying out loud 'just a moment'. She opens the door out to the square where the strollers are parked, looks down into one of the strollers, turns around and closes the door while saying 'no, it wasn't here'. Meanwhile, several children have moved from their place at the mattress and walked out to the floor towards Rikke. Rikke looks at them while saying 'sorry! I am here now'. She directs them back into their places, so that their back touches the mirror. She places herself in the same position as before, reading on using the dolls. A moment later, the boy Sebastian crawls towards the box and his hand reaches out towards one of the dolls. Rikke looks at him, then at Christina, and says 'Sebastian, you have to go back, the other children can't see'. Christina pulls Sebastian back towards the wall. He wiggles and starts to cry. Rikke has continued reading, but now stops in the middle of the sentence, and says 'look Sebastian, in a minute Kaj will be crying too'. She reads on. As Sebastian's crying gets louder, the speed of Rikke's reading increases and she puts on the mask from before, making 'wauhhh' sounds towards Sebastian.' (Observation book $1,2014)$

Dialogic Reading is enacted here as an assemblage of boxes, walls, dolls, a script, a book, a mattress, a tiger mask, children, an assistant and the nursery teacher called Rikke. Here, the book is translated as an object of learning in which words are repeated ('red'), emphasis is put on pronunciation (the ' $t$ ' sounds), dolls are playing out the plot of the book, and questions are asked in regard to the themes and what will happen in the story. The feelings in the book are expressed through Rikke's mimicry and movements (for example, looking surprised or afraid). As such, the categories of phonological awareness and vocabulary, the scripts outlining potential questions that are part of DR as an evidence-based method, become part of the action. As a blackboxed evidencebased method suitable for all Danish day care centres, DR establishes connections between 
categories of language development, 'truths' representing what a child is meant to be, and purposes of ECEC that become central to the kinds of action that seem relevant or needed in the above episode. DR is in this way part of the action. However, this cannot be understood as a mere transmission of knowledge or ideas transforming them into practice. Becoming part of the action implies that DR is enacted; that it is translated and also translates elements of day care. Put differently, this is not just the implementation of an existing method; this is a way of organising children, books, dolls, a tiger mask and a big blue mattress so that they connect with categories of phonological awareness, descriptions of the three steps of DR, and so on. It is an enactment through which DR becomes possible to carry out. The way in which Rikke and the tiger mask connect, and the ways in which they connect the book to the children through the 'wauuhh' sounds, is not a scripted instruction. It is a way of forging links, enrolling children so as to mobilise DR; an effort which is repeated as a (re)enrolment of Sebastian once he starts crying. Thus, to perform DR is not just a matter of acting out a script or transmit scientific knowledge through the means of a method. It is an enactment; a way of establishing a connection between the child, the mattress and the wall so that it becomes stabilised as a place for the child to be read aloud to. And it is a way of creating connections between the book, the child and the toys, so that Rikke can act as a performer of DR.

This also implies that carrying out DR is not just about making use of objects that are already there. In the episode above, the mattress, the book and the toys are translated quite differently than in the episode with Mona, the beanbag and the CD player. Whereas physical engagement seems central to the enactment of the beanbag, this is not the case with the dolls and the tiger mask (Sebastian is prohibited from touching it while the reading goes on). Likewise, touch (lying close to children, stroking their hair, pulling them down) is part of stabilising children's bodies into the restful state enacted through the audio book on the CD player, and the blue mattress. However, once this mattress becomes part of DR, it translates into a place for the children to sit, where they cannot move around, swap places or physically engage with the nursery teacher. Rather, the connection between the wall and the mattress becomes a placement through which it is possible to address the child as a listening and language-developing learner.

In the episode above, DR as a network of action can be said to leak - or nearly fall apart - at several times. First, a possible noise from Catherine in the stroller seems to make DR porous. As Rikke looks up, and asks her assistant, Christina, whether 'it is ours' - that is, whether the child belongs to their group room - it is possible to interpret the gaze from Rikke towards the window and then 
towards Christina as an attempt to forge a link between Christina and the possible sound from the stroller. However, Christina is not mobilised as part of the action, and Rikke gets up instead. So do the children. The places - that is, the connections between the mattress, the wall and the children are now dismantled and must be (re)stabilised when Rikke comes back. Rikke here seems to have difficulties being enrolled as part of DR while simultaneously connecting herself to Catherine's possible cry. She is stretched - so to speak - to the margin of the network, as she has to handle the many elements of everyday life in a day care centre. Second, the dissolving of place during Sebastian's outburst likewise indicates the difficulties of stabilising reality when enacting DR. As Sebastian is pulled back into place, he starts crying. An attempt is made to create a connection between the book, the concept of crying and Sebastian ('look Sebastian, in a minute Kaj will be crying too'). However, as this enrolment seems to fall apart, Rikke not only connects the tiger mask to Sebastian and the earlier laughing experience, she also speeds up her reading as his crying increases. Sebastian's crying can be interpreted as an element threatening to dismantle DR as a network. In the effort of stabilising DR as the core activity, Rikke continues to read aloud, using the tiger mask to (re)enrol Sebastian. However, no more using techniques, such as posing questions, lifting dolls in the air and pronouncing ' $t$ ' sounds.

These cases show that carrying out Dialogic Reading can be something that requires much more work than just acting out a method. Making DR work, in this case at least, involves enrolling and stabilising the reality of everyday life in particular ways; and it involves continuous work to handle and dismantle all of the elements that threaten to dissolve the network of DR. The risk that dolls could be translated into something to play with, that the mattress could be translated as a place to lie down or that the book could be translated as an ongoing activity from which you can get up and move around is continuously present. Handling this complexity and keeping DR steady as an evidence-based method is (one could say) hard work.

\section{Concluding remarks - paradoxes and political ontologies}

In this paper, I have analysed DR as a multiple assemblage in need of continuous work to be stabilised as an evidence-based pedagogy. I have explored this kind of work being carried out at local day care centres, both in terms of the connections forged and efforts made as DR is translated into a method suitable for all Danish day care centres; and in terms of the work put into organising the children, mattress, books, dolls and boxes, while dismantling cries or noises from a child in a stroller. My ambition has not been to criticise DR (or rather the multiple ontologies of DR), but to 
challenge the ideas of evidence-based pedagogy, by showing how a method that 'works' - as if abstract and pure, and transferrable through step-by step guides - is not the outset of implementation. DR is not one thing with inherent properties, but the result of enactments translating and stabilising it in multiple 'evident' forms. Thus, I have questioned the key assumption within evidence-based pedagogy that knowledge in an abstracted, universal form can be transferred through methodological steps handed to the nursery teacher. The evidence-based pedagogy of Dialogic Reading in Denmark, as I have shown, relies on concrete relations that are never enacted once and for all, but require continual work to be held together as a method that 'works'. As such DR cannot be said to be a method that 'works' in and through its inherent qualities based on epistemological insights. However, it is continuously made to work in and through ontological engagements with books, dolls, children, nursery teachers etc.

My point has not been to disagree with the scientific nature of DR. Rather, I will argue that researchers, method as a systematic approach, tests, and test developers are central to DR as an assemblage. Nor is it my point that DR becomes flaunted with political bias because it is related to a governmental interest or because it is made into a commodity. Researchers, test developers, governmental interests, and indeed money, all contribute to the making of DR. This does not make it unscientific or flaunted with political bias, because such a statement would imply that underneath all of this, DR was pure in the first place. Rather than politically biased, I see DR as an act of ontological politics (Mol 1999). I hereby mean that it is a way of forging alliances stabilising reality and making certain interventions possible and logical - and marginalising others. The black boxing of DR as an evident method is a powerful enactment as it hereby holds a position of scientific transcendence that hides the cutting of complexity through which it is made.

The marginalisation can be understood in terms of what is considered to hold professional status. DR - and indeed the whole evidence-based agenda - implies a notion of professionalism, in which the nursery teacher is made professional by applying the scientific knowledge inherent in the method. Also in the Spindle, working with DR is seen as central to the nursery teachers' professionalism, whereas the 'rest-time', or other ways in which the book is translated, are not addressed as part of this professional status. Herein lies a paradox. Thus, stabilising DR as an evidence-based method through which professionalism comes to the fore implies not only that books, dolls and tiger masks are separated from the group room and the everyday activity (put in a closet and taken in when the stage is set); it also means juggling the noise from a stroller, the child 
who moves around or reaches for the dolls or cries, so that these elements are kept on the side-line, preventing DR to fall apart as an evident method. However, all of the effort put into juggling the complexity of DR, so as to keep it as a strictly performed method, is marginalised as professional work. It is neither addressed by the nursery teachers nor part of the scientific reports, the test developers' design or the packages made and sold to day care centres. Put differently, as DR is translated into the Spindle day care centre, links between the children, books, toys, mattress, and so on, continuously need to be dismantled and instead enrolled in other (evident) ways. As such, keeping DR steady as an evident methods that 'works', paradoxically seems to imply a lot of work that is not addressed as professional work..

In the field of ECEC evidence-based pedagogy has been discussed and critiqued as too general and abstract to meet the particular practice and the local needs. It has been argued that though the idea of one size-fits all seems appealing to policy making as another quick fix, these kinds of methods turn practice in to instrumental actions where the development of children potentially becomes a question of fostering narrow and predefined skills (Ede 2006, Hedges 2012, Schmidt 2013a, Parks and Bridges-Rhoads 2012). This paper contributes to the critique of evidence-based pedagogy by dismantling the kind of assumptions it embeds through a concrete example. Thus, my point is not that DR as an evidence-based pedagogy is too general, instrumental or wrongly implemented in the Spindle. My point is that it was never abstract and general in the first place. In fact, it was never one thing. As DR is enacted in the field of ECEC in Denmark it becomes invested and form alliances that differ from those made in the US. Likewise, the enactment of DR in the Spindle continuously imply forging new alliances (with books, a mattress, nursery teachers and children) investing these elements with ideas of language-learning and professionalism. As such I have pursued the multiple connections that make up DR: All the invisible work that goes into making it an evident method that 'works'; and the kind of marginalisation that is carried along with it.

\section{Acknowledgement:}

This work was supported by the Danish Union for Nursery Teachers (Børne og Ungdoms Pædagogernes Landsforbund).

\section{References:}

Ahrenkiel, Annegrethe , Birger Steen Nielsen, Camilla Schmidt, Finn M. Sommer, and Niels Warring. 2012. Daginstitutionsarbejde og paedagogiske faglighed [daycarework and professionalism]. Copenhagen: Frydenlund. 
Ball, Stephen J. 2007. "Intellectuals or technicians? The urgent role of theory in educational studies." In Educational research and evidence-based practice, edited by Martyn Hammersly, 106-120. London: SAGE publications.

Biesta, Gert. 2007. "Why 'what works' won't work. Evidence-based practice and the democratic deficit of educational research." Educational Theory 57 (1):1-22.

Biesta, Gert. 2010. Good education in an age of measurement : ethics, politics, democracy. Boulder, Colo. ; London: Paradigm Publishers.

Bleses, Dorthe. 2011. "Sammenfatning af forskningskortlægning af behov for sprogvurdering, effektive sprogindsatser og pædagogisk efteruddannelse samt praksisunders $\emptyset$ gelse [Resume of the results of the review of the need for languageassesment, effective languageinitiatives and education among pedagogues and analysis of practice] " In: Servicestyrelsen (accessed 17.04.2015).

Brembeck, Helene, Barbro Johansson, and Jan Kampmann. 2004. Beyond the competent child: exploring contemporary childhoods in the Nordic welfare societies. Frederiksberg: Roskilde University Press.

Buus, Anne Mette, Stine Del Pin Hamilton, Merete Wiberg, Palle Rasmussen, Trine Holck Grundahl, and Ulla Nørtoft Thomsen. 2012. En kortlægning af arbejdet med evidensbaserede metoder i daginstitutioner i tre kommuner. [A review of the practicing of evidencebased methods in daycares in three municipalities]. Aalborg Aalborg University.

Callon, Michael. 1986. "Some Elements of a Sociology of Translation: Domestication of the Scallops and the Fishermen of St Briuc Bay." In Power, Action and Belief: A New Sociology of Knowledge, edited by John Law, 196-233. London: Routledge \& Kegan Paul.

Callon, Michael, and John Law. 1997. "After the Individual in Society: Lessons on Collectivity from Science, Technology and Society." Canadian Journal of Sociology 22 (2):165-182.

Cheeseman, Sandra, Jennifer Sumsion, and Frances Press. 2014. "Infants of the knowledge economy: the ambition of the Australian Government's Early Years Learning Framework." Pedagogy, Culture \& Society 22 (3):405-424.

Dahlberg, Gunilla, and Peter Moss. 2005. Ethics and politics in early childhood education. London: RoutledgeFalmer.

Ede, Anita. 2006. "Scripted Curriculum: Is it a Prescription for Success?" Childhood Education 83 (1):29-32.

Fass, Paula S., and Michael Grossberg. 2012. Reinventing childhood after World War II. Philadelphia: University of Pennsylvania Press.

Fenwick, Tara J., and Richard July Edwards. 2010. Actor-network theory in education. 1st ed. ed. London: Routledge.

Foucault, Michel, and Sylve re Lotringer. 2007. The politics of truth. Los Angeles, Calif.: Semiotext(e).

Gordon, Tuula, Janet Holland, and Elina Lahelma. 2001. "Ethnographic Research in Educational Settings." In Handbook of Ethnography, edited by Paul Atkinson, 188-203. London: SAGE publications.

Grek, Sotiria. 2009. "Governning by numbers: the PISA 'effect' in Europe." Journal of Education Policy 24 (1):23-37.

Hamilton, Mary. 2011. "Unruly Practices: What a sociology of translations can offer to educational policy analysis." Educational Philosophy and Theory: Incorporating ACCESS 43 (1):55-.

Hammersley, Martyn. 2007. Educational research and evidence-based practice. Los Angeles ; London: SAGE.

Hansen, Allan Dreyer, Stinne Lyager Bech, and Maja Plum. 2004. Spillet om læring - en diskursanalyse af brugen af læring på dagtilbudsområdet [The Game of Learning - a 
discourseanalysis of how the notion of learning is used in the field of daycare]. Copenhagen: Learning Lab Denmark.

Hedges, Helen. 2012. "Teachers' funds of knowledge: a challenge to evidence-based practice." Teachers and Teaching: theory and practiceAquatic 18 (1):7-24.

Højbjerg, Karin. 2015. "The challenge of establishing a professional practice within practical education." Ethnography and Education 10 (2):185-197.

Jensen, Anders Skriver. 2014. "The Deluge." European Early Childhood Education Research Journal 22 (1):77-90.

Jensen, Mette Nygaard. 2005. Dialogisk oplæsning i dagtilbud [Dialogic Reading in Daycare]. Copenhagen: Learning Lab Denmark.

Kampmann, Jan. 2003. "Barndomssociologi - fra marganaliseret provokatør til mainstream leverandør." Dansk Sociologi 14 (2):79-93.

Krejsler, John. 2013. "What Works in Education and Social Welfare? A Mapping of the Evidence Discourse and Reflections upon Consequences for Professionals." Scandinavian Journal of Educational Research 57 (1):16-32.

Kristensen, Jens Erik. 2015. "Fra daginstitutioner til førskole [From daycare to preschool]." Vera Tidsskrift for Padagoger [Vera - Journal for Nursery Teachers] (70):12-19.

Krogstrup, Hanne Kathrine. 2011. Kampen om evidens [the struggle over evidence]. Copenhagen: Hans Reitzels forlag.

Latour, Bruno. 1999. Pandora's hope : essays on the reality of science studies. Cambridge, Mass. ; London: Harvard University Press.

Latour, Bruno, and Steve Woolgar. 1979. Laboratory life : the construction of scientific facts. 2nd ed. London: Sage Publications.

Law, John. 1994. Organizing modernity: Blackwell.

Law, John. 2003. Traduction/Trahision: Notes on ANT.

Miller, Linda, Carmen Dalli, and Mathias Urban. 2012. Early childhood grows up : towards a critical ecology of the profession. 1st ed. ed. Dordrecht ; New York: Springer.

Mol, Annemarie. 1999. "Ontological Politics. A word and some questions." In Actor-Network Theory and After, edited by John Law and John Hassard. Oxford: Blackwell Publishers.

Mol, Annemarie. 2003. The body multiple : ontology in medical practice. Durham, N.C. ; London: Duke University Press.

Morrow, Robert W. 2006. Sesame Street and the reform of children's television. Baltimore, Md. ; London: Johns Hopkins University Press.

Mulchany, Dianne. 2006. "This salience of space for pedagogy and identity in teacher education: problem-based learning as a case in point." Pedagogy, Culture \& Society 14 (01):55-69.

Nespor, Jan. 2004. "Educational Scale-Making." Pedagogy, Culture \& Society 12 (3):309-326.

Osgood, Jayne. 2009. "Childcare workforce reform in England and 'the early years professional': a critical discourse analysis." Journal of Education Policy 24 (6):733-751.

Parks, Amy Noelle, and Sarah Bridges-Rhoads. 2012. "Overly Scripted: Exploring the Impact of a Scripted Literacy Curriculum on a Preschool Teacher's Instructional Practices in Mathematics." Journal of Research in Childhood Education 26 (3):308-324.

Pettersvold, Mari, and Solveig Østrem. 2012. Mestrer. Mestrer ikke. Jakten på det normale barnet. [Competent. Not competent. The hunt for the normal child]. Oslo: Res Publica.

Plum, Maja. 2012a. "The emergence of the analytical method in early childhood education - the scientific effort to produce the learning child for the nation in a global era." International Journal of Qualitative Studies in Education 25 (5):645-664. 
Plum, Maja. 2012b. "Humanism, Administration and Education: The Demand of Documentation and the Production of a New Pedagogical Desire." Journal of Education Policy 27 (4):491508.

Plum, Maja. 2014. "A 'globalised' curriculum - international comparative practices and the preschool child as a site of economic optimisation." Discourse: Studies in the Cultural Politics of Education 35 (4):570-583.

Plum, Maja. 2015. "Signing in: Knowledge and Action in Nursery Teaching." 2015.

Pole, Christopher, and Marlene Morrison. 2003. Ethnography for education. Buckingham: Open University Press.

Prout, Alan. 2005. The future of childhood: towards the interdisciplinary study of children, The future of childhood series. London: RoutledgeFalmer.

Schmidt, Camilla. 2013a. "Vidensudveksling og daginstitutionsarbejde sat på manual [Knowledge exchange and daycare work put on a script]." In Kampen om daginstitutionen [The strugle over the daycare institution], edited by John Benedicto Krejsler, Annegrethe Ahrenkiel and Camilla Schmidt. Frederiksberg: Frydenlund.

Schmidt, lene S.K. 2013c. "Sprogtest - når ord får betydning? [language tests - when words are given meaning?]." Ph.d, Department of Media, Cognition and Communication, University of Copenhagen.

Socialministeren. 2003. Forslag til lov om ændring af lov om pædagogiske læreplaner. In $L 124$, edited by Socialministeriet: www.retsinformation.dk.

Steinnes, Gerd Sylvi. 2014. "Common sense or professional qualifications? Division of labour in kindergartens." Early Childhood Education Research Journal 22 (4):478-495.

Sørensen, Estrid. 2009. The Materiality of Learning: Technology and Knowledge in Educational Practice. New York: Cambridge University.

Urban, Mathias. 2008. "Dealing with uncertainty: challenges and possibilities for the early childhood profession." European Early Childhood Education Research Journal 16 (2):135152.

Vandenbroeck, Michel, Griet Roets, and Rudi Roose. 2012. "Why the evidence-based paradigm in early childhood education and care is anything but evident." European Early Childhood Education Research Journal 20 (4):532-552.

Whitehurst, G. J., F. L. Falco, C. J. Lonigan, J. E. Fischel, B.D. DeBaryshe, Valdez-Menchaca M. C., and M. Caulfield. 1988. "Accelerating Language Development Through Picture Book Reading." Developmental Psychology, 24 (4):552-559.

Wyatt, Tasha R. 2014. "Teaching across the lines: adapting scripted programmes with culturally relevant/responsive teaching." Pedagogy, Culture \& Society 22 (3):447-469.

Zevenbergen, Andrea A., Grover J. Whitehurst, and Jason A. Zevenbergen. 2003. "Effects of a shared-reading intervention on the inclusion of evaluative devices in narratives of children from low-income families." Applied Developmental Psychology 24:1-15.

\footnotetext{
${ }^{\mathrm{i}}$ It should be noted that this notion of professionalism - and the implicit ontological and epistemological assumptions about knowledge and action it entails - is highly criticized in the field of ECEC (see Plum 2015, Miller, Dalli, and Urban 2012). Though the evidence-based agenda carries a particular notion of professionalism, I would argue that this must be seen in relation to classical theories of profession. In the classical sense, a profession is defined by having a demarcated and independent knowledge base on which the professional ground his practice (Højbjerg 2015, Steinnes 2014). Evidence-based initiatives can in this way be seen as a way of importing knowledge into the practice of nursery teaching thereby grounding nursery teachers' actions on a knowledge base, thereby making them professional.
} 


\footnotetext{
${ }^{i i}$ See descriptions of The Language Package: http://www.sprogpakken.dk/4dag/dialogisk.php; The Mary Foundation: http://www.xn--lseleg-pua.dk/dialogisk-laesning and in (Jensen 2005)

iii The name of the day care centers and the persons observed are de-identified and therefore anonymous.

${ }^{\text {iv }}$ I hereby mean that the ethnographical attempt to understand the meaning-making going on was heavily related to the elements part of the doing: Inspired by ANT perspectives, I gave a lot of attention not only to what people said and how they made sense of what they were doing; but continually sought to direct attention to the different elements such as cups, diapers, books etc. and how they were part of this doing.

${ }^{v}$ PISA stands for the Programme for International Student Assessment. It is conducted by the Organisation for Economic Co-operation and Development (OECD). Denmark became part of the PISA programme in 1997. Since then, the PISA reports have been published every third year with high media coverage, pushing the call for political action to address what is seen as poor learning results. Thus, 28 revisions of the law on the Danish comprehensive school system have been made since the first PISA report (Plum 2014).

${ }^{v i}$ All translations are done by me.

${ }^{\text {vii }}$ Within the area of language development and language testing there are competing truths across the field of audiologopedics and social linguistics. In Denmark, social linguistics has been prominent in relation to bilingual children, but not in relation to language development as a general theme related to child development (Schmidt 2013c, 11-15).

${ }^{v i i i}$ The Mary Foundation : http://www.xn--lseleg-pua.dk/dialogisk-laesning; and the Language Packet: http://www.sprogpakken.dk/4dag/dialogisk.php

${ }^{\mathrm{ix}}$ See: http://xn--lseleg-pua.dk/om-laeseleg

${ }^{x}$ See also: http://sprogpakken.dk/kommune/index.php

${ }^{x i}$ See: http://www.maryfonden.dk/da/om-ekspertpaneler
} 